\title{
MODEL MENTAL MAHASISWA CALON GURU KIMIA DALAM MEMAHAMI BAHAN KAJIAN STEREOKIMIA
}

\author{
I Wayan Suja \\ Jurusan Pendidikan Kimia \\ Universitas Pendidikan Ganesha \\ E-mail: suja_undiksha@yahoo.co.id
}

\begin{abstract}
Abstrak
Penelitian ini bertujuan untuk: (1) menentukan distribusi model mental mahasiswa calon guru kimia dalam memahami bahan kajian Stereokimia, serta (2) mengidentifikasi dan mendeskripsikan miskonsepsi khusus (specific misconceptions) dan model mental alternatif yang dimiliki oleh mahasiswa calon guru kimia. Subyek penelitian adalah mahasiswa Jurusan Pendidikan Kimia FMIPA UNDIKSHA yang sedang mengambil mata kuliah Kimia Organik III di Kelas C Semeter V pada tahun ajaran 2013/2014. Jumlah subyek penelitian sebanyak 28 orang. Data dikumpulkan melalui instrumen tes hasil belajar berbentuk pilihan ganda dua tingkat, terdiri dari bagian isi dan bagian alasan. Analisis data dilakukan secara deskriptif. Hasil penelitian menunjukkan,(1) model mental mahasiswa calon guru kimia dalam memahami bahan kajian Stereokimia adalah: tidak ada konsep $(20,71 \%)$, miskonsepsi spesifik $(33,04 \%)$, model mental alternatif $(12,50 \%)$, dan benar secara ilmiah (33,75\%); serta (2) miskonsepsi tertinggi $(92,86 \%)$ terjadi pada penentuan konfigurasi $(\mathrm{R} / \mathrm{S})$ senyawa berdasarkan proyeksi Newman, dan model mental alternatif tertinggi $(32,14 \%)$ pada penggambaran proyeksi Fischer stereoisomer yang diketahui konfigurasi absolutnya.
\end{abstract}

Kata kunci: model mental, stereokimia, miskonsepsi, model mental alternatif.

\begin{abstract}
This study aims to: (1) determine the distribution of mental models chemistry student teachers in understanding the study materials stereochemistry, and (2) identify and describe special misconceptions (specific misconceptions) and alternative mental models held by student teachers of chemistry. Subjects were students of the Department of Chemistry Education UNDIKSHA who are taking courses in Organic Chemistry III, Class C meter V in the academic year 2013/2014. The number of study subjects were 28 people. Data were collected through achievement test multiple choice of two levels, consists of the contents and part of the reason. The data were analyzed descriptively. Results showed that (1) the mental models chemistry student teachers in understanding the study materials stereochemistry is: there is no concept of $(20.71 \%)$, specific misconceptions (33.04\%), alternative mental models $(12.50 \%)$, and scientifically true $(33.75 \%)$; and (2) the highest misconceptions $(92.86 \%)$ occurred in the determination of the configuration ( $\mathrm{R} / \mathrm{S}$ ) compounds based on projections of Newman, and alternative mental models the highest $(32.14 \%)$ in the depiction of the Fischer projection stereoisomer of known absolute configuration.
\end{abstract}

Keywords: mental models, stereochemistry, misconceptions, alternative mental models.

\section{PENDAHULUAN}

Stereokimia merupakan studi tentang struktur tiga dimensi molekul (Wade, 2006), yang mencakup tiga aspek, yaitu: isomer geometri, konformasi, dan kiralitas molekul (Morrison \& Boyd, 1989). Ketiga aspek tersebut merupakan landasan untuk memahami struktur dan reaktivitas senyawa. Bahan kajian stereokimia menjadi menarik karena menggabungkan aspek geometri, topologi, dan struktur kimia dalam studi bentuk tiga dimensi molekul. Bahan kajian tersebut juga menjadi penting karena tubuh makhluk hidup dibentuk oleh unit-unit kiral, seperti asam amino, nukleotida, dan gula, yang secara alami 
ada dalam bentuk enantiomer murni. Kiralitas molekul menjadi penting dalam kaitan dengan pemanfaatan senyawa organik, yang menjadi target transformasi dan sintesis senyawasenyawa bahan obat (Schreiner et al., 2011). Kondisi itu menyebabkan stereokimia merupakan bahan kajian yang sangat penting dalam bidang kimia organik, namun sering dipandang sulit oleh sebagian mahasiswa.

Kemampuan untuk memahami dan menerapkan hubungan antara struktur dan sifat senyawa merupakan kompetensi inti dalam pembelajaran kimia. Namun, berbagai hasil penelitian menunjukkan bahwa sebagian besar pebelajar harus berjuang keras agar bisa memahaminya (Kind dalam Maeyer \&Talanquer, 2013). Gagasan bahwa sifat makroskopik materi muncul dari interaksi partikel-partikel materi sulit dipahami oleh mahasiswa. Sebaliknya, penalaran akal sehat sering menyebabkan mereka menganggap bahwa sifat makroskopis dihasilkan dari rerata sifat komponen-komponen penyusunnya (Talanquer, 2006). Di sisi lain, temuan penelitian Maeyer \&Talanquer (2013) menunjukkan, dalam menjelaskan sifat zat, banyak mahasiswa mengandalkan pena-laran intuitif dan beberapa mengalami miskonsepsi.

Ide-ide dalam pikiran pebelajar yang digunakannya untuk menggambarkan, menjelaskan, dan memprediksi sebuah fenomena dinamakan model mental (Jansoon, 2009; Wang, 2007). Pembentukan model mental dipengaruhi oleh pengalaman dan pengetahuan awal pebelajar, sikap dan keyakinan mereka, serta persoalan-persoalan yang dihada-pinya. Dalam kaitan dengan pembelajaran kimia, model mental dibangun melalui proses pengamatan, penafsiran, penjelasan, imaginasi, dan pemahaman wacana ilmiah (Chittleborough, 2004; Jansoon, 2009). Sebelumnya, Glynn \& Duit (1995) merekomendasikan agar model mental dianggap sebagai bagian penting dari kerangka konseptual pebelajar, yang oleh Jansoon (2009), digambarkan sebagai irisan interkoneksi ketiga level kimia, sebagaimana ditampilkan pada Gambar 1.

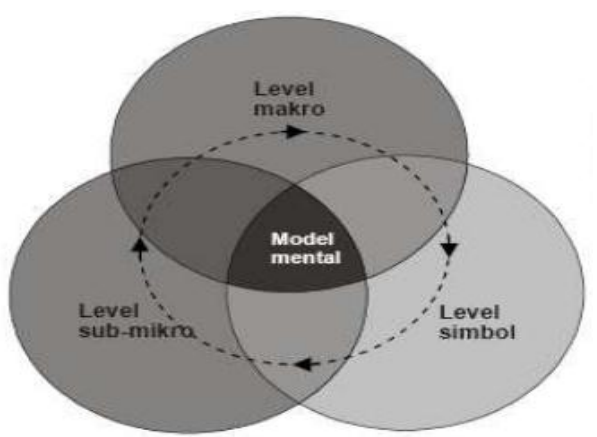

Gambar 1. Keterkaitan Tiga Level Kimia dengan Model Mental

Model mental yang sesungguhnya dalam pikiran pebelajar sangat rumit dan sulit digambarkan, namun memungkinkan untuk digali dari ekspresi mereka tentang suatu fenomena atau pemecahan masalah. Model mental seseorang pada umumnya diselidiki melalui penafsiran atas model yang diekspresikan dalam berbagai bentuk, yang oleh Bouter \& Buckley dalam Park (2006) dikategorikan menjadi lima tipe, yaitu model visual, model simbolik, model gerak isyarat, model objek nyata, dan model verbal. Kualitas model mental pebelajar ditentukan berdasarkan kesesuaiannya dengan model konseptual yang telah diakui oleh masyarakat ilmiah dan ketepatannya untuk memprediksi dan menjelaskan fenomena alam. Selain itu, deskripsi model mental kimia pebelajar berhubungan dengan triplet kimia, yang meliputi level makroskopis, submikroskopis, dan simbolik, serta interkoneksi ketiga level tersebut (Andini, 2010; Maulana, 2011).

Model mental adalah representasi pribadi mental seseorang terhadap suatu ide atau konsep. Model mental dapat digambarkan sebagai model konseptual, representasi mental/internal, gambaran mental, proses mental, suatu konstruksi yang tidak dapat diamati, dan representasi kognitif pribadi (Chittleborough,2007: 278). Model mental dalam organisasi belajar menurut Senge (2002: 279-280), merupakan gambaran, asumsi dan 
kisah yang dibawa dalam benak setiap individu tentang dirinya sendiri, orang lain, lembaga-lembaga dan setiap aspek dari dunia luar.

Menurut Buckley \& Boulter (2007:7) model mental adalah representasi intrinsik benda, ide atau proses yang dihasilkan individu selama fungsi kognitif. Pembelajar menggunakan model untuk mengemukakan alasan, mendeskripsikan, menjelaskan, memprediksikan suatu fenomena dan menghasilkan model ekspresi dalam berbagai format (misalnya deskripsi verbal, diagram, simulasi atau model kongkrit).

Menurut Franco dan Colinvaux (2007: 22) disimpulkan empat karakteristik model mental, yaitu: 1 . Model mental adalah generatif: model mental dapat mengawali informasi baru dengan memanfaatkan model mental tersebut untuk meramalkandan untuk menghasilkan penjelasan. 2. Model mental melibatkan pengetahuan yang tidak dapat diucapkan: individu menggunakan model mental mereka untuk memecahkan suatu Masalah atau memahami informasi baru, tetapi mereka mungkin tidak menyadari terhadap model mental yang mereka miliki dan bagaimana mereka menggunakannya. 3. Model mental adalah sintetik: sebuah model mental adalah dinamis dan terus menerus dimodifikasi sesuai informasi baru yang dimasukkan kedalamnya. 4.Model mental dipengaruhi oleh dunia yang dilihat: pengembangan dan penerapan model mental dipengaruhi oleh pengetahuan individu sebelumnya, pengalaman, dan keyakinan.

Menurut Coll \& Treagust dalam Wang (2007:25) model mental dibagi 3 tipe, yaitu model mental ilmiah, model mental konseptual dan modelmental alternatif. Hal ini sejalan dengan pendapat yang dikemukan Chittleborough (2004: 198), bahwa model mental siswa dipengaruhi oleh model ilmiah/konsensus dan model pengajar. Model mental yang dihasilkan siswa kemudian berkembang dan menjadi lebih kompleks, dan memungkinkan terjadinya modifikasi terhadap konsep dan hubungannya. Model mental yang dimilki dan digunakan siswa dalam menyelesaikan permasalahan, menjawab pertanyaan dan membuat prediksi yang ditunjukan sebagai model yang ditampilkan (expressed model).

Konstruksi model mental adalah inti dari suatu pembelajaran bermakna, dimana dalam memahami dan menalar bagaimana suatu sistem bekerja, seorang individu perlu menyusun suatu model mental diotaknya terhadap sistem yang dihadapinya tersebut. Setiap individu dalam tahap ini akan membangun jaringan konsepkonsep terkait dan memahami hubungan fungsional dari sejumlah aspek dan tingkatan yang berbeda dari sistem tersebut (Abdullah, 2006 dalam Sunyono, 2012: 9). Model mental yang dianalisis dalam penelitian ini merupakan model-model yang diekspresikan (expressed models) sebagai eksternal model mental, yang merupakan hasil dari internal model mental oleh responden yang diteliti.

Sunyono, Leny Yuanita, dan Muslimin Ibrahim. 2011. Model Mental Pebelajar Tahun Pertama dalam Mengenal Konsep Stoikiometri (Studi Pendahuluan pada Pebelajar Program Studi Pendidikan Kimia FKIP Universitas Lampung. Prosiding Seminar Nasional V.6 Juli 2011. Yogyakarta: Universitas Islam Indonesia.

Sehubungan dengan model mental dalam memahami hubungan antara struktur molekul dengan sifat senyawa, pada penelitian ini telah dilakukan analisis model mental mahasiswa calon guru kimia dalam memahami bahan kajian stereokimia. Bahan kajian tersebut memuat struktur Model tiga dimensi molekul dan kontribusinya terhadap kereaktivan senyawanya. Analisis model mental dilakukan terhadap mahasiswa semester $\mathrm{V}$ ke atas yang sedang mengambil mata kuliah Kimia Organik III dan telah mengambil Kimia Organik I dimana bahan kajian stereokimia tersebut diajarkan. Tujuan penelitian ini 
adalah: (1) menentukan distribusi model mentalmahasiswa calon gurukimia dalam memahami bahan kajian stereokimia, serta (2) mengidentifikasi dan mendes-kripsikan miskonsepsi khusus (specific misconceptions) dan model mental alternatif yang dimiliki oleh mahasiswa calon guru kimia. Dengan mengetahui miskonsepsi dan model mental alternatif mahasiswa, memungkinkan untuk melakukan tindak lanjut berupa remidiasi secara bertahap dan berkelanjutan pada mata-mata kuliah rumpun Kimia Organik.

\section{METODE}

Penelitian ini dilaksanakan di Jurusan Pendidikan Kimia,Fakultas MIPA, UNDIKSHA pada semester ganjil tahun ajaran 2013/2014. Subjek penelitiannya adalah mahasiswa yang sedang menempuh Mata Kuliah Kimia Organik III, di Kelas C, sebanyak 28 orang.

Penelitian dirancang mulai dari tahapan: (1) penyusunan instrumen, (2) validasi instrumen, (3) uji coba instrumen, (4) pengumpulan data, (5) analisis data hasil penelitian, serta (6) pelaporan dan publikasi hasil penelitian. Instrumen yang digunakan adalah tes hasil belajar yang dirancang khusus untuk mengidentifikasi model mental mahasiswa dalam memahami bahan kajian stereokimia, berupa tes pilihan ganda dua tingkat (twotier test), yang terdiri dari bagian isi dan bagian alasan. Bagian pertama memuat respon mahasiswa terhadap pilihan jawaban yang disediakan berkaitan dengan konten; sedangkan bagian kedua, menuntut mahasiswa agar memberikan alasan atas jawabannya pada bagian pertama (Coll dalam Wang, 2007).

Menurut Senduret al.,(2010), model mental pebelajar dapat dikelompokkan menjadi empat kategori berikut.

a. Tidak ada jawaban/tanggapan (No Response/ NR), jika pebelajar tidak memberikan jawaban dan tidak membuat alasan, atau menjawab dengan penjelasan tidak berkaitan dengan pertanyaan. Istilah untuk tipe ini adalah tidak ada konsep.

b. Miskonsepsi khusus pada hal tertentu (Specific Misconceptions/ $S M)$, yaitu ketika jawaban dan penjelasan tidak dapat diterima secara keilmuan.

c. Benar sebagian (Partially Correct/PC) jika jawaban benar secara keilmuan, namun penjelasan/alasan tidak benar; atau jawaban tidak benar secara keilmuan, namun penjelasannya benar. Tipe ini dikenal sebagai model mental alternatif.

d. Benar secara keilmuan (Scientifically Correct/SC), jika jawaban dan penjelasan benar secara keilmuan.

Model mental demikian sering juga disebut model mental tipe I sampai IV, yang masing-masing berkaitan dengan tidak ada tanggapan (NR), terjadi miskonsepsi (SM), model mental alternatif (PC), dan model mental ilmiah (SC).

\section{HASIL DAN PEMBAHASAN}

Hasil penelitian berupa distribusi model mental mahasiswa calon guru kimia dalam memahami bahan kajian stereokimia dapat dilihat pada Tabel 1.

Tabel 1. Rekapitulasi Model Mental Mahasiswa Calon Guru tentang Stereokimia

\begin{tabular}{clcccccccc}
\hline \multirow{2}{*}{ NS Indikator } & \multicolumn{7}{c}{ Model Mental } \\
\cline { 2 - 9 } & NR & $\% N R$ & SM & $\% S M$ & PC & \% & SC & $\%$ \\
\hline 1 & 2 & 7,14 & 3 & 10,71 & 1 & 3,57 & 22 & 78,57 \\
& $\begin{array}{l}\text { Menentukan isomer geometri } \\
\text { alkena. }\end{array}$ & 12 & 42,86 & 7 & 25,00 & 2 & 7,14 & 7 & 25,00 \\
11 & $\begin{array}{l}\text { Menentukan isomer geometri } \\
\text { sikloalkana }\end{array}$ & 1 & 3,57 & 0 & 0,00 & 2 & 7,14 & 25 & 89,29 \\
2 & $\begin{array}{l}\text { Memprediksi kestabilan } \\
\text { konformasi molekul alkana. }\end{array}$ & 11 & 39,29 & 10 & 35,71 & 3 & 10,71 & 4 & 14,29
\end{tabular}




\begin{tabular}{|c|c|c|c|c|c|c|c|c|c|}
\hline \multirow[b]{2}{*}{ NS } & \multirow[b]{2}{*}{ Indikator } & \multicolumn{8}{|c|}{ Model Mental } \\
\hline & & NR & $\% N R$ & SM & $\% S M$ & PC & $\begin{array}{l}\% \\
\text { PC }\end{array}$ & SC & $\begin{array}{l}\% \\
\text { SC }\end{array}$ \\
\hline 3 & $\begin{array}{l}\text { geometri sikloalkana } \\
\text { terdisubstitusi. } \\
\text { Membandingkan titik lelehisomer- } \\
\text { isomer geometri asam } \\
\text { butenadioat. }\end{array}$ & 5 & 17,86 & 19 & 67,86 & 3 & 10,71 & 1 & 3,57 \\
\hline 13 & $\begin{array}{l}\text { Membandingkan titik didihisomer- } \\
\text { isomer geometri senyawa } \\
\text { alkanadiol. }\end{array}$ & 8 & 28,57 & 17 & 60,71 & 2 & 7,14 & 1 & 3,57 \\
\hline 4 & $\begin{array}{l}\text { Membandingkan kontribusi } \\
\text { bentuk-bentuk konformer } \\
\text { terhadap keasaman senyawanya. } \\
\text { Menjelaskan keasaman senyawa }\end{array}$ & 13 & 46,43 & 7 & 25,00 & 4 & 14,29 & 4 & 14,29 \\
\hline 14 & $\begin{array}{l}\text { berdasarkan struktur isomer } \\
\text { geometrinya. } \\
\text { Menentukan hubungan antara }\end{array}$ & 15 & 53,57 & 5 & 17,86 & 7 & 25,00 & 1 & 3,57 \\
\hline 5 & $\begin{array}{l}\text { struktur isomer geometri molekul } \\
\text { dengan kelarutannya dalam air. } \\
\text { Menentukan kontribusi }\end{array}$ & 4 & 14,29 & 7 & 25,00 & 6 & 21,43 & 11 & 39,29 \\
\hline 15 & $\begin{array}{l}\text { bentukkonformasi } 1,2 \text {-alkanadiol } \\
\text { terhadap kelarutan senyawanya } \\
\text { dalam air. } \\
\text { Menentukan analoai vana palina }\end{array}$ & 9 & 32,14 & 6 & 21,43 & 9 & 32,14 & 4 & 14,29 \\
\hline 6 & $\begin{array}{l}\text { relevan dengan sifat kiralitas } \\
\text { senyawa. }\end{array}$ & 0 & 0,00 & 0 & 0,00 & 2 & 7,14 & 26 & 92,86 \\
\hline 16 & $\begin{array}{l}\text { Menentukan analogi yang paling } \\
\text { relevan dengan sifat akiral } \\
\text { senyawa. } \\
\text { Menerapkan hubungan antara }\end{array}$ & 2 & 7,14 & 2 & 7,14 & 2 & 7,14 & 22 & 78,57 \\
\hline 7 & $\begin{array}{l}\text { keberadaan unsur-unsur simetri } \\
\text { molekul dengan aktivitas } \\
\text { optiknya. }\end{array}$ & 4 & 14,29 & 1 & 3,57 & 7 & 25,00 & 16 & 57,14 \\
\hline 17 & $\begin{array}{l}\text { Menentukan hubungan antara } \\
\text { unsur-unsur simetri molekul } \\
\text { senyawa siklik dengan kiralitas } \\
\text { senyawanya. }\end{array}$ & 11 & 39,29 & 12 & 42,86 & 2 & 7,14 & 3 & 10,71 \\
\hline 8 & $\begin{array}{l}\text { Menentukan konfigurasi absolut } \\
\text { (R/S) senyawa berdasarkan } \\
\text { struktur tiga dimensinya. } \\
\text { Menentukan konfigurasi (R/S) }\end{array}$ & 6 & 21,43 & 10 & 35,71 & 4 & 14,29 & 8 & 28,57 \\
\hline 18 & $\begin{array}{l}\text { senyawa berdasarkan proyeksi } \\
\text { Fischernya. } \\
\text { Menentukan konfigurasi (R/S) }\end{array}$ & 4 & 14,29 & 3 & 10,71 & 2 & 7,14 & 19 & 67,86 \\
\hline 9 & $\begin{array}{l}\text { senyawa berdasarkan proyeksi } \\
\text { Newmanya. } \\
\text { Menentukan proyeksi Newman }\end{array}$ & 1 & 3,57 & 26 & 92,86 & 0 & 0,00 & 1 & 3,57 \\
\hline 19 & $\begin{array}{l}\text { senyawa yang diketahui nama } \\
\text { IUPACnya lengkap dengan } \\
\text { konfigurasi absolutnya }(R / S)\end{array}$ & 1 & 3,57 & 18 & 64,29 & 2 & 7,14 & 7 & 25,00 \\
\hline 10 & $\begin{array}{l}\text { Menggambar proyeksi Fischer } \\
\text { stereoisomer yang diketahui } \\
\text { konfigurasi absolut atom-atom } \\
\text { karbon kiralnya. } \\
\text { Menentukan stereoisomer }\end{array}$ & 3 & 10,71 & 9 & 32,14 & 9 & 32,14 & 7 & 25,00 \\
\hline 20 & $\begin{array}{l}\text { senyawa yang diketahui proyeksi } \\
\text { Fischernya. }\end{array}$ & 4 & 14,29 & 23 & 82,14 & 1 & 3,57 & 0 & 0,00 \\
\hline & Total & 116 & 20,71 & 185 & 33,04 & 70 & 12,50 & 189 & 33,75 \\
\hline
\end{tabular}


SM (Specific Misconceptions) = jumlah mengalami miskonsepsi,

PC $($ Partially Correct $)=$ jumlah model mental alternatif,

SC (Scientifically Correct) $=$ jumlah model mental ilmiah.

Data dalam Tabel 1 di atas menunjukkan, $78,57 \%$ mahasiswa telah memiliki model mental ilmiah berkaitan dengan penentuan senyawa alkena yang memiliki isomer geometri. Pemahaman mereka ada pada levelsimbolik dan mampu menampilkannya dalam bentuk model visual berupa rumus struktur alkena. Penguasaan model mental ilmiah mahasiswa calon guru pada pemahaman isomer geometri ternyata menurun pada senyawa siklik (hanya mencapai $25,00 \%$ ), dan sebagian besar $(42,86 \%)$ tidak memiliki konsep. Kondisi itu mengindikasikan, sebagian besar mahasiswa tidak mampu menggambarkan struktur molekul senyawa, sehingga mereka tidak bisa menentukan letak dan orientasi substituen-substiuennya. Pada kemampuan untuk memprediksi kestabilan bentuk-bentuk konformasi molekul, sebagian besar mahasiswa $(89,29 \%)$ telah memiliki model mental ilmiah. Model mentalnya ada pada level simbolik dan mampu menampilkannya dalam bentuk model visual berupa proyeksi Newman. Namun, kemampuan tersebut tidak muncul pada saat digunakan untuk menjelaskan kestabilan isomerisomersikloalkana terdisubstitusi yang melibatkan konsep konformasi dan isomer geometri. Sebanyak 39,29\% tidak memiliki konsep berkaitan dengan masalah tersebut; $35,71 \%$ mengalami miskonsepsi; 10,71\% memiliki model mental alternatif, dan hanya 14,29\% memiliki model mental ilmiah. Rendahnya model mental ilmiah mahasiswa pada masalah tersebut disebabkan mereka masih mengalami miskonsepi, yang memandang setiap isomer trans selalu lebih stabil dibandingkan isomer cis-nya.

Sebagian besar mahasiswa mengalami miskonsepsi (di atas $60,00 \%$ ) dalam menjela-skan titik didih dan titik leleh senyawa, serta sebagian lagi memiliki model mental alternatif.
Mereka yang mengalami miskonsepsi mengaitkan polaritas senyawa dengan titik didih dan titik leleh senyawanya. Molekul-molekul yang lebih polar, dalam hal ini asam maleat diprediksi memiliki titik leleh lebih tinggi dibandingkan asam fumarat. Hal yang sama juga terjadi pada penentuan titik didih isomer-isomer geometri senyawa siklobutanadiol. Di sisi lain, tipe model mental alternatif memandang titik didih dan titik leleh berkaitan dengan kestabilan senyawa. Menurut mereka, diperlukan energi yang lebih besar untuk memutuskan ikatan dalam struktur molekul yang lebih stabil, sehingga titik didih atau titik leleh senyawanya menjadi lebih tinggi. Dalam hal ini, jawaban mereka benar, namun alasannya salah.

Titik didih dan titik leleh senyawa sesungguhnya tidak berkaitan dengan polaritas dan kestabilan molekul,tetapi dengan interaksi antar molekulmolekulnya. Semakin kuat gaya tarik antar molekulnya, semakin tinggi titik didih atau titik leleh senyawa tersebut. Dalam kasus yang diberikan, titik didih ditentukan oleh keberadaan ikatan hidrogen intermolekuler dan intramolekuler. Ikatan hidrogen antar molekul menyebabkan titik didih dan titik leleh senyawa lebih tinggi dibandingkan isomer lain yang mengalami ikatan hidrogen intramolekuler. Selain itu, proses mendidih atau meleleh sebagai bentuk perubahan fisika tidak melibatkan pemutusan ikatan antar atom dalam molekul. Untuk menjelaskan hal itu,mahasiswa harus menguasai model mental level submikroskopis partikel materi didukung dengan model mental level simboliknya.

Lemahnya

pemahaman mahasiswa berkaitan dengan korelasi struktur molekul dan kereaktivan senyawa juga tampak pada kemampuannya untuk memprediksi kontribusi bentuk konformasi molekul terhadap kekuatan asam senyawanya. 
Sebagian besar mahasiswa $(46,43 \%)$ tidak memiliki konsep, dan 25\% mengalami miskonsepsi. Mereka yang tidak memiliki konsep tidak mengetahui hubungan antara bentuk konformasi dengan kekuatan asam. Sedangkan, yang mengalami miskonsepsi rata-rata memandang konformasi gaus memiliki keasaman paling tinggi karena mampu membentuk ikatan hidrogen intramolekuler yang bersifat stabil. Di sisi lain, yang memiliki tipe model mental alternatif $(14,29 \%)$ menyatakan bentuk eklips penuh menyumbangkan sifat keasaman paling kuat karena terjadi tolak-menolak antar gugus hidroksil yang saling berimpit, sehingga lebih mudah melepaskan ion $\mathrm{H}^{+}$. Sesungguhnya, keasaman senyawa asam 2,3-dimetilbutanadioat memang paling tinggi disumbangkan oleh konformasi gausnya, namun disebabkan oleh terjadinya ikatan hidrogen intramolekuler antar kedua gugus $-\mathrm{OH}$ yang saling berimpit. Struktur tersebut menyebabkan lebih mudah melepaskan ion $\mathrm{H}^{+}$.

Sejalan dengan penentuan sifat keasaman senyawa asam butanadioat, sebagian besar mahasiswa $(53,57 \%)$ juga tidak memiliki konsep untuk membandingkan kekuatan asam maleat (bentuk cis) dengan asam fumarat (bentuk trans). Sebanyak $25 \%$ mahasiswa memiliki model mental alternatif. Mereka mengetahui keasaman asam maleat lebih kuat dibandingkan dengan asam fumarat, namun alasannya tidak tepat. Penjelasan mereka berkaitan dengan kelarutan senyawa. Menurutnya, asam maleat lebih mudah larut dalam air, sehingga lebih mudah terionisasi untuk menghasilkan ion $\mathrm{H}^{+}$. Sedangkan, argumentasi ilmiah berkaitan dengan keasaman senyawa asam maleat dikaitkan dengan kemampuannya untuk membentuk ikatan hidrogen intramolekuler yang berdampak pada kemudahan untuk melepaskan ion $\mathrm{H}^{+}$.

Pada penentuan kelarutan isomer geometri dalam air, sebagian besar mahasiswa $(39,29 \%)$ telah memiliki model mental ilmiah dengan mengaitkan polaritas senyawa dengan kelarutannya. Asam maleat lebih polar dibandingkan asam fumarat, sehingga kelarutan asam maleat dalam air lebih tinggi dibandingkan asam fumarat. Sebagian di antaranya (25,00 \%) mengalami miskonsepsi, dan $21,43 \%$ memiliki model mental alternatif. Mereka yang mengalami miskonsepsi menyatakan asam fumarat lebih mudah larut dalam air karena lebih mampu membentuk ikatan hidrogen dengan molekul-molekul air. Di sisi lain, mahasiswa yang memiliki model mental alternatif memperkirakan asam maleat lebih mudah larut dalam air karena adanya ikatan hidrogen intramolekuler, karena kurang stabil, dan juga karena titik lelehnya lebih rendah. Ketidakmampuan mahasiswa untuk menjelaskan fenomena makroskopis berkaitan dengan kelarutan senyawa disebabkan oleh kurangnya kemampuan untuk melakukan penalaran pada tingkat submikroskopis, walaupun mereka sudah mampu memvisualisasikan dalam bentuk rumus struktur pada level simbolik.

Berkaitan dengan kontribusi bentuk konformer senyawa 1,2etanadiol terhadap kelarutannya, proporsi mahasiswa yang tidak memiliki konsep sama dengan yang memiliki model mental alternatif, yaitu sebanyak $32,14 \%$; sedangkan yang memiliki model mental ilmiah hanya mencapai $14,29 \%$. Rendahnya kemampuan mahasiswa untuk memprediksi kelarutan senyawa disebabkan ketidakmampuannya dalam menjelaskan fungsi struktur molekul terhadap sifat makroskopis senyawanya. Sesungguhnya, kelarutan senyawa dalam air ditentukan oleh polaritas senyawa, dan dalam konteks struktur konformasi, polaritas tertinggi dimiliki oleh konformasi dengan gugus-gugus $-\mathrm{OH}$ pada posisi eklips penuh (momen dipol terbesar). Dalam kasus ini, mahasiswa harus mampu menggambar dan memvisualisasikan struktur tiga dimensi molekul dan memprediksi polaritasnya. Semakin besar resultan vektor momenmomen gugus senyawa, polaritasnya semakin kuat, sehingga kelarutannya 
dalam air semakin besar. Di sisi lain, mahasiswa yang memiliki model mental alternatif memandang kelarutan senyawa 1,2-etanadiol dalam air ditentukan oleh kemudahannya untuk membentuk ikatan hidrogen antara molekul-molekul alkohol tersebut dengan molekul-molekul air sebagai pelarut.

Model mental mahasiswa dalam memilih analogi untuk menjelaskan kiralitas senyawa tergolong sangat baik (rerata 85,72\%). Kondisi itu disebabkan mahasiswa telah menguasai ciri-ciri senyawa kiral secara benar dan analogi yang ditampilkan dalam bentuk objek nyata secara makroskopis telah akrab dengan kehidupan mahasiswa. Akibatnya, sebagaian besar mahasiswa memiliki model mental ilmiah berkaitan dengan analogi kiralitas senyawa organik.

Dalam penentuan aktivitas optik senyawa rantai terbuka yang telah diberikan nama lengkap dengan konfigurasi absolutnya (R/S), model mental ilmiah mahasiswa mencapai $57,14 \%$ dan model mental alternatifnya sebesar $25,00 \%$. Tingginya kebenaran ilmiah yang dicapai mahasiswa sebagian besar berupa model mental verbal. Mereka tidak menggambar struktur molekul senyawa lengkap dengan konfigurasi absolut (R/S) dan bayangan cerminnya, namun secara deskriptif menyatakan bahwa molekul yang memiliki bidang simetri (senyawa meso) bersifat inaktif optik. Dengan demikian, walaupun mahasiswa telah memiliki model mental ilmiah, namun belum tentu memahami level simbolik dan submikroskopis molekul cara tepat.

Cukup tingginya persentase model mental ilmiah mahasiswa pada penentuan aktivitas optik senyawa rantai terbuka tidak seiring dengan kemampuannya untuk menentukan aktivitas optik senyawa siklik. Sebagian besar $(42,86 \%)$ mahasiswa mengalami miskonsepsi dan sebagian tidak memiliki konsep $(39,29 \%)$ pada penentuan kiralitas senyawa siklik yang struktur ruangnya memiliki bidang simetri atau pusat simetri. Mahasiswa yang mengalami miskonsepsi memandang sifat inaktif optik senyawa siklik hanya ditentukan oleh keberadaan bidang simetrinya, tanpa mencermati ada tidaknya atom karbon kiral atau unsur-unsur simetri lainnya. Dengan demikian, model mental mahasiswa secara umum belum cukup memadai untuk menentukan aktivitas optik senyawa organik.

Model mental ilmiah hanya dimiliki oleh $28,57 \%$ mahasiswa dalam menentukan konfigurasi absolut (R/S) senyawa berdasarkan struktur tiga dimensinya, dan mencapai 67,86\% berdasarkan proyeksi Fischernya (dua dimensi). Kondisi itu menunjukkan, sebagian besar mahasiswa mengalami kesulitan dalam membayangkan struktur tiga dimensi molekul dalam pikirannya. Kesulitan tersebut menyebabkan mereka tidak mampu menentukan konfigurasi absolut senyawa pada pusat kiralnya. Pada saat diberikan struktur Fischer senyawa, mahasiswa dapat menggunakan strategi tertentu untuk menentukan konfigurasi absolutnya pada pusat-pusat kiral tanpa memahami struktur tiga dimensinya. Atas dasar itu, kemampuan mahasiswa untuk memvisualisasikan struktur tiga dimensi molekul dalam pikirannya masih sangat perlu ditingkatkan.

Model mental mahasiswa belum mampu melakukan konversi dari proyeksi Newman menjadi struktur tiga dimensinya. Akibatnya, sebagian besar mereka tidak bisa menentukan konfigurasi absolut (R/S) senyawa berdasarkan struktur proyeksi Newmannya, dan $78,58 \%$ di antaranya mengalami miskonsepsi. Kondisi yang sama juga terjadi pada penentuan konfigurasi absolut senyawa yang memiliki beberapa pusat kiral berdasarkan proyeksi Fischernya. Pada aspek tersebut, jumlah mahasiswa yang mengalami miskonsepsi mencapai 82,14\%. Dengan demikian, sebagian besar mahasiswa belum mampu menentukan dan memvisualisasikan struktur tiga dimensi senyawa dalam pikirannya dari proyeksi Newman dan proyeksi Fischer. Data tersebut juga dibuktikan 
dari tingginya miskonsepsi yang dialami mahasiswa pada saat menggolongkan jenis isomer optik beberapa pasangan senyawa yang telah diketahui proyeksi Fischernya.

Secara umum, model mental ilmiah mahasiswa calon guru kimia dalam memahami bahan kajian stereokimia hanya mencapai $33,75 \%$. Nilai tersebut hanya sedikit di atas persentase miskonsepsi khusus yang mencapai 33,04\%. Tingginya miskonsepsi kimia dan banyaknya model mental alternatif yang dimiliki mahasiswa calon guru kimia disebabkan oleh berbagai faktor,yang secara umum dikelompokkan menjadi faktor eksternal dan internal.

Faktor eksternal yang mempengaruhi terjadinya miskonsepsi dan model mental alternatif di antaranya adalah buku-buku teks kimia yang digunakan oleh guru dan siswa pada saat mereka masih ada di bangku SMA berpeluang menimbulkan terjadinya miskonsepsi(Suja \& Retug, 2013a,b). Kondisi itu disebabkan miskonsepsi bersifat sangat resisten, sehingga sulit dihilangkan. Faktor internal yang berpotensi menimbulkan terjadinya miskonsepsi dan model mental alternatif pada mahasiswa calon guru adalah sebagai berikut.

Pertama, ketidakmampuan mereka memilih atribut esensial dari sejumlah ciri umum yang dimiliki oleh sebuah konsep (Ibrahim, 2012). Sebagai contoh, jika dalam rumus struktur senyawa terdapat beberapa pusat kiral dan juga bidang simetri (bidang khayalan yang membelah suatu senyawa menjadi dua bagian, sehingga setiap bagian menjadi bayangan cermin dari bagian yang lainnya), maka senyawa tersebut bersifat inaktif optis. Di sisi lain, jika tidak mengandung atom karbon kiral, walaupun tidak memiliki bidang simetri, senyawa tersebut tidak bersifat aktif optis. Dengan demikian, atribut utama senyawa bersifat aktif optis adalah mengandung atom karbon kiral, bukan pada tidak adanya bidang simetri. Misalnya, senyawa trans-1,3-dibromo1,3-dinitro-siklobutana bersifat tidak aktif optis karena tidak mengandung atom kiral. Tetapi, sebagian besar mahasiswa menyebutnya bersifat aktif optis karena tidak memiliki bidang simetri.

Kedua, kekeliruan penalaran. Kekeliruan penalaran terjadi karena ketidakpahaman mahasiswa tentang level submikroskopis kimia. Sebagai contoh, dalam menjelaskan perubahan wujud zat, berkaitan dengan titik didih dan titik leleh senyawa, banyak mahasiswa mengira proses tersebut melibatkan pemutusan ikatan dalam molekul (ikatan kovalen), bukan ikatan atau interaksi antar molekul (gaya van der Waals atau ikatan hidrogen). Mahasiswa menjelaskan titik didih dan titik leleh senyawa berdasarkan kestabilan strukur molekulnya. Semakin stabil struktur molekul suatu senyawa, semakin kuat ikatan antar atom-atomnya, sehingga titik didih atau titik lelehnya semakin tinggi. Kekeliruan penalaran tersebut menyebabkan mahasiswa menjelaskan titik leleh asam fumarat yang lebih tinggi daripada asam maleat bukan karena ikatan hidrogen yang terjadi antar molekul-molekul asam fumarat, tetapi karena lebih stabil dibandingkan asam maleat (model mental alternatif).

Kekeliruan penalaran juga terjadi pada saat mahasiswa menjelaskan perbedaan kelarutan antara asam maleat dan asam fumarat dalam air. Perbedaan kelarutan kedua isomer asam 1,3-butenadioat tersebut seharusnya dijelaskan berdasarkan perbedaan kepolarannya. Asam maleat (isomer cis) memiliki momen dipol (bersifat polar), sehingga lebih mudah larut dalam air. Sebaliknya, asam fumarat tidak memiliki momen dipol (non polar), sehingga tidak larut dalam air. Secara skematis, penentuan kepolaran kedua senyawa tersebut dapat ditentukan dengan penjumlahan vektor momen-momen gugusnya. 
<smiles>O=C1C=CC(C(=O)O)C(=O)O1</smiles>

$\mu \gg 0$

Asam maleat (bentuk cis)

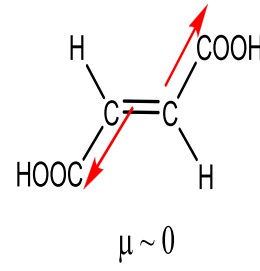

Asam fumarat (bentuk trans)

Mahasiswa yang mengalami miskonsepsi menjelaskan kelarutan kedua senyawa asam tersebut tidak berdasarkan kepolarannya, tetapi menurut kemudahannya dalam membentuk ikatan hidrogen dengan molekul-molekul air. Berbeda dengan fakta ilmiahnya, mahasiswa mengira asam fumarat lebih mudah larut dalam air karena lebih mudah membentuk ikatan hidrogen dengan molekulmolekul air.

Ketiga, kekeliruan pemikiran intuitif. Pemikiran intuitif muncul tibatiba karena masalah tersebut telah dianggap umum. Sebagai contoh, bagi sebagian besar mahasiswa, isomer trans selalu dipandang lebih stabil dibandingkan isomer cis. $\mathrm{Hal}$ itu disebabkan jarak antar gugus-gugus yang sama pada isomer trans saling berjauhan, sehingga gaya tolakmenolak antar gugus-gugus tersebut menjadi sangat rendah. Dengan demikian, isomer trans lebih stabil dibandingkan isomer cis, yang letak gugus-gugusnya ada pada sisi yang sama. Sesungguhnya, kestabilan molekul sikloalkana tersubstitusi mesti dilihat dari struktur tiga dimensinya. Sebagai contoh, dalam tes yang diberikan, siswa memprediksi struktur senyawa trans-1,3-dimetilsikloheksana lebih stabil dibandingkan isomer cisnya. Sedangkan, konformasi isomer cis lebih stabil karena mampu membentuk struktur ekuatorialekuatorial $(e, e)$ yang menyebabkan tidak terjadi tolak-menolak antar gugusgugus metil yang terikat pada rantai sikloheksana tersebut, sebagaimana ditampilkan di bawah ini.

Isomer geometri 1,3-imetilsikloheksana:<smiles>CC1CCCC(C)C1</smiles><smiles>C=CC1CCCC(C)(CC)C1C</smiles>

$(\mathrm{e}, \mathrm{a})$

$(\mathrm{a}, \mathrm{e})$

Trans-1,3-dimetilsikloheksana<smiles>CC1CCCC(C)C1</smiles>

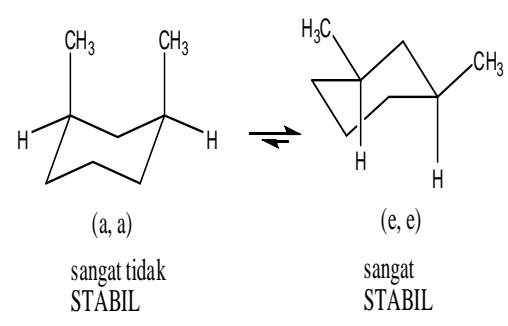

Cis-1,3-dimetisikloheksana
Keempat, kekurangan informasi yang dimiliki peserta didik tentang kompleksitas permasalahan yang dikajinya (Furió \& Calatayud, 1996). Kekurangan informasi yang dimiliki oleh mahasiswa dalam model mentalnya di antaranya tampak pada saat mereka menggambar terjadinya ikatan hidrogen antar molekul-molekul asam fumarat, yang menyebabkan titik leleh asam fumarat lebih tinggi dibandingkan asam maleat.

Model mental ilmiah:

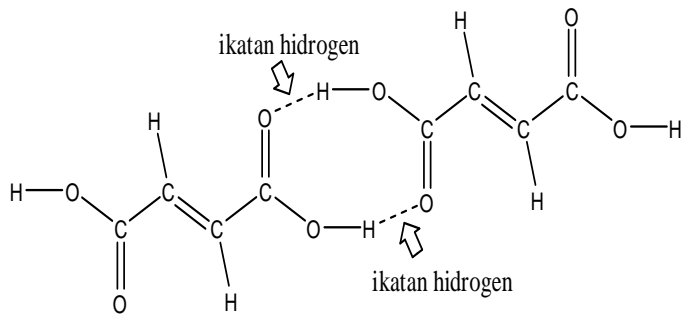

Model mental alternatif (mahasiswa):<smiles>O=C(O)/C=C/C(=C\C(=O)O)O[IH]OC(=O)C=C(O)O</smiles>

Kurangnya informasi juga tampak pada saat mereka menentukan konfigurasi absolut (R/S) senyawa 
berdasarkan proyeksi Newman atau proyeksi Fischer.

Secara umum, terjadinya miskonsepsi, model mental alternatif, dan juga tidak ada konsep pada diri mahasiswa calon guru kimia menunjukkan bahwa mereka belum memahami bahan kajian stereokimia, yang mencakup level makroskopis, level submikroskopis, level simbolik, dan interkoneksi ketiga level tersebut secara komprehensif.

\section{SIMPULAN DAN SARAN}

Sejalan dengan hasil penelitian dan pembahasan di depan dapat ditarik simpulan sebagai berikut. Pertama, model mental mahasiswa calon guru kimia dalam memahami bahan kajian Stereokimia adalah: tidak ada konsep $(20,71 \%)$, miskonsepsi spesifik $(33,04 \%)$, model mental alternatif $(12,50 \%)$, dan benar secara ilmiah $(33,75 \%)$. Kedua, miskonsepsi tertinggi $(92,86 \%)$ terjadi pada penentuan konfigurasi $(\mathrm{R} / \mathrm{S})$ senyawa berdasarkan proyeksi Newmannya, dan model mental alternatif tertinggi (32,14\%) pada penggambaran proyeksi Fischer stereoisomer yang diketahui konfigurasi absolutnya.

Untuk mengubah dan membentuk model mental mahasiswa, sehingga menjadi model mental ilmiah, pembelajaran Kimia Organik seharusnya dilakukan dengan pengamatan fenomena makroskopis berkaitan dengan bahan kajian yang akan dipelajarinya. Selanjutnya, mahasiswa diberikan kesempatan untuk menjelaskan fenomena tersebut secara molekuler yang melibatkan pemahaman kimia pada level submikroskopis. Untuk membantu mahasiswa agar mereka mampu memvisualisasikan kimia pada level molekuler, pembelajaran mesti didukung dengan penggunaan model molekul, misalnya menggunakan molymod. Selanjutnya, model mental mahasiswa yang sudah terbentuk melalui kegiatan pembelajaran mesti diuji dengan model-model konseptual yang telah disepakati oleh para pakar kimia. Model mental tersebut juga harus diperkuat dengan aplikasinya dalam pemecahan masalah.

\section{DAFTAR PUSTAKA}

Andhini, R., 2010. Profil Model Mental Siswa pada Pokok Bahasan Senyawa Hidro Karbon. Skripsi FPMIPA Jurusan Pendidikan Kimia. Bandung: Universitas Pendidikan Indonesia.

Chittleborough, G., 2004. The Role of Teaching Models and Chemical Representations in Developing Student's Mental Model of Chemical Phenomena. Tesis Doktor in Curtin University of Technology.

Furió, C., \& Calatayud, M. L., 1996. Difficulties with the geometry and polarity of molecules. Journal of Chemical Education, 73: 36-41.

Glynn, S. M., \&Duit, R., 1995. "Learning science meaningfully: Constructing conceptualmodel." In S. M. Glynn \& R. Duit (Eds.), Learning science in the schools:Research reforming practice (pp. 3-33). Mahwah, $\mathrm{NJ}$ : Lawrence ErlbaumAssociates.

Ibrahim, M., 2012. Seri Pembelajaran Inovatif: Konsep, Miskonsepsi, dan Cara Pembelajarannya. Surabaya: Usesa University Press.

Jansoon, N., 2009. Understanding Mental Models of Dilution in Thai Students. International Journal of Environmental \& Science Education. 4(2): 147 168.

Maeyer, J., \&Talanquer, V., 2013. Making Predictions about Chemical Reactivity: Assumptions an Heuristics. Journal of Research in Science Teaching, 50(6): 748-767.

Maulana, Y., 2011. Profil Model Mental Mahasiswa Calon Guru Kimia Tingkat Pertama pada Beberapa Konsep Dasar Ikatan Kimia. Skripsi Fakultas FPMIPAJurusan Pendidikan 
Kimia. Bandung: Universitas Pendidikan Indonesia.

Mayer, L., 2010. Addressing Students' Misconceptions about Gases, Mass, and Composition. Journal of Chemical Education, 88(1): $111-115$.

Morrison, R.T., \& Boyd, R.N., 1989. Organik Chemistry. $5^{\text {th }}$. New Delhi: Prentice Hall of India.

Park, E. J., 2006. Student Perception and Conceptual Development as represented by Student Mental Models of Atomic Structure. Ohio State University.

Schreiner, E., Trabuco, L. G., Freddolino, P. L., \& Schulten, K., 2011. Stereo-chemical errors and their implications for molecular dynamics simulations. BMC Bioinformatics, 12:190 199.

http://www.biomedcentral.com/1 471-2105/12/190

Sendur, G., Toprak, M., Pekmez, E., 2010. Analyzing of Students' Misconcep-tions about Chemical Equilibrium. Paper on International Conference on New Trends in Education and Their Implications. AntalyaTurkey.

Suja, I W., \& Retug, N., 2013a. Propil Konsepsi Kimia Siswa Kelas XI di Kota Singaraja. Prosiding Senari (Seminar Nasional Riset Inovatif) Lembaga Penelitian Universitas Pendidikan Ganesha ke-1 ISSN 2339-1553. Tahun 2013. Halaman 172 179.

Suja, I W., \& Retug, N., 2013b. Konsepsi Kimia Siswa Kelas XII di Kota Singaraja. Prosiding Seminar Nasional FMIPA UNDIKSHA III Tahun 2013. Halaman 125 - 133.

Talaquer, V., 2006. Commonsense chemistry: A model for understanding student'salternative conceptions. Journal of
Chemical Education, 83:811816.

Wade, L. G., 2006. Organic Chemistry. $\quad 6^{\text {th }} \quad$ edition. Singapore: Pearson Education, Inc.

Wang, Ch. Y., 2007. The role of mentalmodelling ability, content knowledge, and mental model in general chemistry students' understanding about moleculer polarity.

Dissertationpresented tothe Faculty of the Graduate SchoolUniversity of Missouri Columbia

Sunyono. 2012. Analisis Model Pembelajaran Berbasis Multipel Representasi dalam Membangun Model Mental Stoikiometri

Mahasiswa.Laporan Hasil

Penelitian Hibah Disertasi Doktor_2012.Lembaga

PenelitianUniversitas Negeri Surabaya

Senge, Peter.et.all. (2002). Shool That Learn: A Fifth Discipline Resource.London: Nicholas Brealey Publishing.

Chittleborough, G. D. \& Treagust D.F. (2007). The modeling ability of non-major chemistry students and their understanding of the sub-microscopic level. Chemistry Education Research and Practice, 8:274-292.

Buckley, B. C., and Boulter, C., J. (2007). Investigating the Role of Representations and Expressed Model in Building Mental Models. In J. K. Gilbert and C. J. Boulter (Eds.), Developing Models In Science Education (119-135). Netherlands: Kluwer Academic Publishers.

Wang, Chia yu (2007). The Role of Mental Modeling Ability, Content Knowledge, and Mental Models in General Chemistry Students' Understanding About Moleculer Polarity. Columbia: The Faculty of the Graduate School University of Missouri 